\title{
Empowering Teachers in the Socialization of the Anti- Sexual Violence Behavior in Primary Schools
}

\author{
https://doi.org/10.3991/ijim.v12i8.9641 \\ Eko Sediyono( $\left.{ }^{\square}\right)$ \\ IEEE Computer Society, Indonesia Chapter \\ eko@staff.uksw.edu \\ Wahyuni Kristinawati, Mila Chrismawati Paseleng \\ SatyaWacana Christian University, Salatiga, Indonesia
}

\begin{abstract}
Facts showed that many cases of sexual harassment and violence occurred to elementary school students, yet they did not have the knowledge, courage, and skills to withstand against the people who harmed them. Teachers should become a good mediator for the students in understanding the basic sexual values, as well as skills against sexual abuses. This study developed a multimedia-based teaching media, animation, and user-friendly digital books to empower these teachers. The other aim to be achieved was the formation of communication and parent-student-teacher partnership. Hence, they were integrated into attaining one purpose which was protecting children from sexual violence. The method used was discussion forums, in where the teachers were divided into small groups, to achieve the goal which was the empowerment action among elementary school teachers in socialising of anti-sexual violence behaviour. All teachers involved were the principals and teachers of two elementary schools in Salatiga, Central Java, Indonesia. The impact of this action program was the establishment of tranquillity and comfort in the community's social life. The teachers were increasingly skilled and encouraged to have courage in socialising anti-sexual violence to the students. The teacher-student-parent communication was able to assist them in making an early identification, and appropriate responses to sexual violence occurred to the elementary students."
\end{abstract}

Keywords — teacher training, anti-sexual violence, multimedia

\section{Introduction}

The cases of sexual violence to children have been on the critical point and tend to increase every year. According to The Commission of Children's Protection of Indonesia (Komisi Perlindungan Anak Indonesia/KPAI), there were thousands cases of sexual violence from 2011-2013, in which 30-48 percent was sexual violence to children [1]. Sexual violence is a traumatic case which leaves very deep "footprints" in the life of an individual because it causes both prolonged traumatic impacts even until adulthood and physical or health problems in later days as well. Traumatic impacts caused by sexual violence experienced by children such as betrayal or distrust from 
children towards adults; traumatic sexuality; powerlessness; and stigmatization. Physical impacts are not always visible because it depends on the types and degree of the violence, but mentally, those who become victims of sexual violence would become addicted, traumatic, even avenged. If it is not seriously treated, it would create greater social problem in the society [1]. Case studies on 17 survivors of sexual violence in the United States who aged above 40 years old, they stated that they faced such traumatic incidents in various ways. Some of them had experienced repeated violence when they were teenagers which made them felt ashamed, blamed themselves, and depression. Some efforts done to manage their emotions were using drugs, alcoholic drinks, and committing in prostitution, whereas the others becoming perfectionists. In their adulthood, traumatic experiences of sexual violence haunted them when choosing spouses and also in parenting [2]. The history of childhood sexual violence predicts low ability and ineffectiveness of parenthood. This condition is worse for groups experiencing sexual violence as well as physical violence [2].

Within three years (2013-2016) cases of violence including sexual violence in Salatiga (Central Java, Indonesia) occurred several times. Cases of sexual violence included cases of sexual violence against children ( 5 years old) with the perpetrators were children aged between 8-9 years old (bp3akb.jatengprov.go.id.assets). The Head of the Government Information Center (Bapermas) of Salatiga stated that the treatment of child sexual abuse cases in Salatiga is still inadequate (Solo Pos, February 2017). Based on experience during some community assistance, cases of abuse that lead to sexual violence also occurred in some schools in Salatiga. A school principal stated that the students needed to gain an understanding of the definitions of sexual harassment and violence and the possible impacts on an individual (personal interview, May 2016). Moreover, in order to keep the surrounding community insightful about the importance of protecting children from the dangers of sexual violence, holistic socialization is needed not only among the children but also among parents and teachers as well. It is hoped that this activity can make the socialization participants become agents of change for the environment so that sexual violence can be anticipated, and if it is happened, then the environment is able take appropriate actions.

The priority issues in terms of sexuality education could be summarized as follows:

a) Inadequate treatment of impacts especially the psychological impacts of the survivors and perpetrators especially if the perpetrator is in the child aged category.

b) Inadequate understanding among children and parents about the definitions of sexual abuse and other abuses and how to prevent them.

c) Inadequacy of teachers' and parents' insights on how to socialize the risks and impacts of sexual violence on children.

d) Inadequate interactive media that could be used by adults in anti-sexual-violence socialization.

Furthermore, the other priority issue in the social aspect is the need for empowerment to build parent-student-teacher partnership so that it becomes holistic strategy in achieving the goal of protecting children from sexual violence. 


\section{$2 \quad$ Literature Review}

Efforts to reduce the number of sexual violence while minimizing the impact is to socialize anti-sexual violence behavior through community empowerment. The antisexual violence socialization curriculum that has been run in Ohio [3] is a class-based curriculum with emphasis on 'Three R' training, which are Recognize, Resist, and Report. Recognize: helping children, teachers, and parents to recognize the rights of children, the definitions of sexual violence, any potential victims and potential perpetrators. Besides, helping them to understand that sexual violence is never a child's fault, and to know that there is possibility of the existence of such survivors or incidents around them. Resist (rejects): teaching children how to reject invitations and coercion that would lead to sexual violence. Parents and teachers were taught to be a child's companion to do this both at school and at home. Report: encouraging children and teachers to work together as a protector for all students. They were also obliged to report if such cases occurred in their schools.

The program also increased the children's knowledge of sexual violence by teaching some basic concepts (that boys and girls could become victims, that the perpetrators could be a stranger or other child who is close to them, and that sexual violence is never a child's fault).

In an effort to prevent the occurrence of sexual violence to children, the parents and teachers were enabled to effectively teach the children on how to protect themselves by providing sufficient knowledge and skills about "Three R" and the introduction about their own bodies to the children.

According to research done by [3], the delivery technique is more influential than who the facilitator is, therefore the delivery technique needs to be packaged in such a way that the information or knowledge provided is easily understood by the socialization targets of anti-sexual violence to children. Ref. [4][5] stated that the more real a person's experiences in obtaining information, the more information will be remembered. People will remember more information when it is obtained from observing and hearing than by merely reading or listening. Moreover, the more senses involved in obtaining information, the greater the proportion of information that will be remembered and it will enable someone to apply and even evaluate their knowledge. Multimedia can be used as a medium of learning in order to implement this experience.

Multimedia is a computer-based media that uses various types of media in an integrated activity [6]. Multimedia will be more effective when the user can manipulate and control the presentation such as start and stop the presentation or slow it down so that they can adjust to the speed of learning [7]. The presentation of animation in multimedia helps to visualize a complex and difficult phenomenon to be observed becomes easier to understand and form more specific concepts and encourage learners to explore more [8] Animation also makes learning activities more fun as it provides interactive activities in building clear conceptual thinking [9]. Hence, interactive multimedia-based animation has enormous potential to support the socialization of Anti Sexual Violence Behavior on Children. One form of multimedia-based animation applications which could be used easily is the info-graphic video media. It has a sim- 
ple yet modern design with an eye-catching look that is effective for emphasizing important information. Through the utilization of this media workshop, socialization of anti-sexual violence behavior for teachers could be more effective. Teachers could easily understand the knowledge needed for socialization of anti-sexual violence behavior to children and use it for socialization among the parents as well.

\section{Methods}

This action research aimed to provide solutions for problems faced by the partner community by involving a team of psychologists, education consultants and supported by the utilization of Information Technology (IT). The targets of the activities were two elementary school partners namely SD SidorejoLor 1, and SD SidorejoLor 5 in Salatiga - Central Java, Indonesia, involving the school principals and all teachers of those two schools. Socialization materials referred to the based socialization curriculum by emphasizing the 'Three R' training which is Recognize, Resist, and Report [3].This material was packaged in animation media in the form of video and presented to the teachers during the workshop which was attended by 15 teachers from SD SidorejoLor 1 , and 10 teachers of SD SidorejoLor 5. The workshop activities were divided into 4 sessions. The first session was the pre-test in where the teachers filled out open-ended questionnaires to assess the teacher's understanding of the importance of anti-violence socialization, the teacher's understanding of the must-be-taught knowledge to the students to prevent the occurrence of sexual violence. This session was followed by brainstorming and Focused Group Discussion (FGD) based on their observations on CSA cases and personal experiences in socializing non-sexual violence behavior. The next activity was the delivery of materials using media that had been developed. The media was multimedia-based animation in the form of infographic video. An example of the content of the material presented in the info-graphic video as shown in Figure 1.

Figure 1.a. showed the headline news in the newspaper, while figure 1.b. explained the increasing sexual violence among the children. It was shown by increasing graphs each year (figure 1.b). Figure 1.c explained some wrong and misleading things in presenting information on the subjects of sexuality and body organs. Figure 1.d. explained the difference of men represented by the father, and women represented by the mother. Figure 1.e and f. each explained the male and female sexual organs. The last media cover was shown in Figure 1.g. which explained that men-women, children, and adults as natural beings and they were not supposed to worry about the differences among them.

This media could be presented through the projector and accessed via Smartphone in order to strengthen and explore the teachers' understanding on the topic being discussed. At the end of the sessions, an evaluation was conducted to check the teachers' understanding about the workshop using questionnaires containing critical questions about their knowledge of sexual violence, its impact and prevention efforts referring to "Three R". 


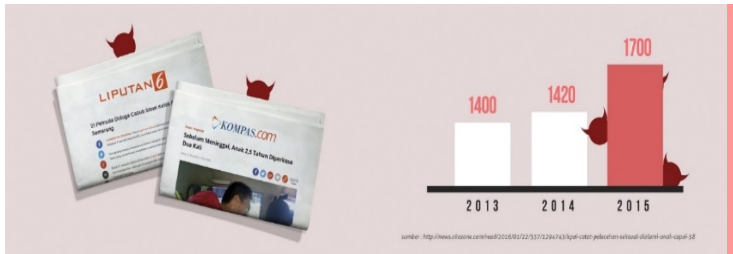

(a) (b)

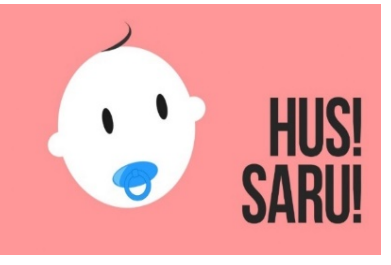

(c)

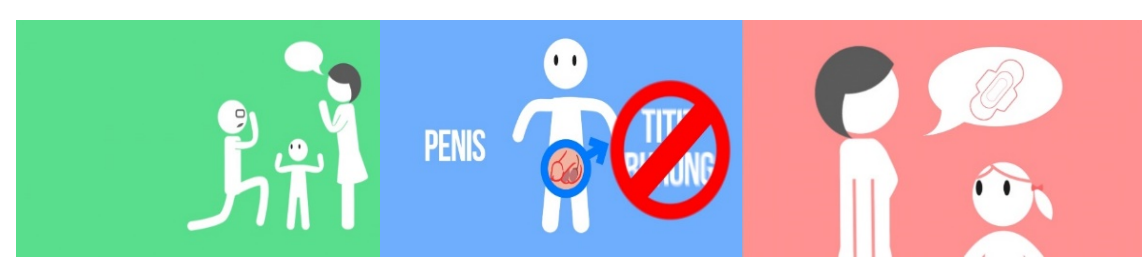

(d)

(e)

(f)

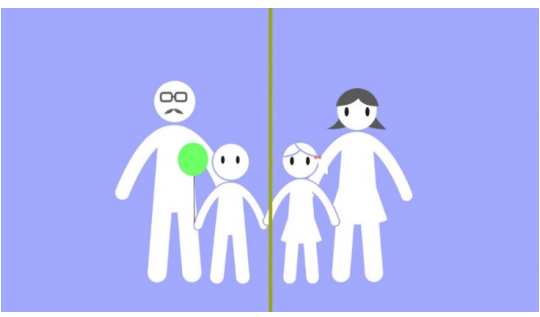

(g)

Fig. 1. Example of the content of Anti-Sexual Violence's materials [15].

\section{Data Analysis}

The data obtained from this research was qualitative data, which was information in the form of opinion of the teachers of FGD participants and also the result of filling out the questionnaires. The data obtained was analyzed by reducing the information obtained from the FGD results and the teachers' answers to the questionnaires through coding based on knowledge components related to Recognize, Resist, Report and other supporting knowledge. The questionnaires' data at the beginning and end of the session were compared to assess the teachers' knowledge change on the same question items. The results of data reduction was then presented in the matrix form so it would be easier to identify the relationship between the information obtained. The conclusions were drawn from the results of this presentation on the needs and benefits of workshop which was attended by those teachers in order to equip them to socialize behavior to students by the teachers as well as by the parents. 


\section{$5 \quad$ Results}

At the initial meeting the participants were very enthusiastic. It was found from the submitted questionnaires that the teachers generally understood that there was a child protection law, but they were not able to name the law exactly. Most of the teachers were able to identify actions or behavior that were considered to be sexual abuses to children. They had been preventing child sexual violence by providing ethical, religious, and behavioral insights, but they were not able to explain the critical questions related to this issue raised by their students. The teachers had been informed about the prevention of sexual violence to children from various parties, but it was not accompanied by adequate media so that they were not able to recall it. They also were reluctant to provide in-depth information about sexuality and violence of sexuality to children because of fear of giving incorrect teachings or information. In addition, there was an assumption that sexuality was taboo and not supposed to be discussed openly.

From FGDs conducted after presentation using the info-graphic videos, teachers became more open in asking or giving opinions about cases of sexual violence or other problems they were facing in teaching their students about sexual education or even about sexual violence. For instance, about how they should respond when there were students asking about viewing animals doing sexual activities. Furthermore, the teachers could also simulate how they should present about recognizing their own bodies without feeling awkward and in a non-vulgar way. Moreover, the teachers' concerns about the importance of anti-sexual violence socialization also increased. It could be seen from the answers given as questionnaire results at the end of the sessions. On the questions about the knowledge needed to provide and how to socialize it, the teachers provided more complete answers which included Recognize, Resist and Report as well as various ideas of presenting the socialization.

\section{Discussions}

Besides parents, teachers also play very great roles in the development of children. Even some parents consider teachers as those who are responsible for their children's education, especially elementary school teachers. It means that teachers' responsibility is not only limited to academic abilities but also knowledge and skills of other life values, in which one of them is related to the prevention of sexual violence. Therefore, one of the efforts to socialize anti-sexual violence behavior to children is through primary school education which involves teachers and parents. Considering the constraints faced so far on the limitations of knowledge, the culture within the community that discussing matters related to sexual education is considered as taboo, and the circumstances in which violent cases are always muted or covered, it indicates the lack of teachers' awareness and cares for the occurrence of sexual violence to children [16]. Such condition was also indicated by the results of the questionnaires at the beginning of the workshop. Therefore, the activity in the workshop helped the teachers to generate the socialization of anti-sexual violence behavior to children. The activity started with a briefing for teachers as agents who have the potentials to follow 
up the socialization for the students and parents. Through the use of animation-based media in the form of info-graphic video, the teachers became more concerned with the importance of socializing anti-sexual violence behavior to children which was started with sexual education at an early age and continued with "Three R".

The teachers' responses to the workshop activities by utilizing the video showed positive results. The use of info-graphic videos with clear narratives, as well as the animation that visualized the narrative presented, enabling the information absorbed more effectively. Similar results were found in groups of children that the best method of presenting non-violent sexual training were behavioral skill trainings combined with movie program or other media [3][11]. It was also found that the teachers attending the training did not feel bored and sleepy. When being asked to fill out the post material presentation questionnaires, they managed to answer questions well and gained higher awareness of campaigning and taking actions of anti-sexual violence among children. In addition, their participation in the activities had shown as improved self-efficacy among teachers as was found by Fryda in [12] and the research results in parental groups in child abuse prevention programs [11].

Furthermore, in the discussion activities, those teachers also stated that the examples provided by the facilitators about teachers as the perpetrators of sexual violence in some areas in Indonesia could give a wrong generalization about the role of teachers. Related to this issue, there was a need for a spirited passion among the teachers so that they become a driving machine which works more effectively to function as a part of the social welfare system for children and families [1]. The positive results demonstrated by teachers in knowledge and attitudes toward the prevention of sexual violence to children, would then provide the potential for successful community empowerment (teachers, parents and students) in the socialization of anti-sexual violence to children. Zhang in his research on the evaluation of sexual violence prevention education of pre-school students in China stated that the success such education did not require knowledge and skill trainings only for children but also for adults around the group [13].

\section{Conclusion}

Based on the discussion and research conducted, it could be concluded that the presentation of information by utilizing multimedia technology in simple, interesting and varied way such as an animation-based media in the form of info-graphic videos improved retention and facilitated the teachers in understanding the information related to anti-sexual violence, which then could be used to continue the socialization for colleagues and parents. In addition, the form of presentation and media also helped the teachers to eliminate obstacles that distracted them to be more open in providing sexual education for students and in socializing anti-sexual violence behavior as an effort to provide knowledge and prevention skills for the students. 


\section{$8 \quad$ Limitations and Future Studies}

The material presented in accordance to the proposed curriculum which consisted only one material. Therefore, in the future, it would be developed Material 2 and 3 as it was planned. In addition, more complete locations and respondents would also be provided by involving the teachers and parents of $S D$ SidorejoLor 1 and 5 and also $S D$ Kumpulrejo, Salatiga, Central Java, Indonesia.

Furthermore, for the next meeting, it is necessary to think about identifying participants' past experiences in sexual violence as it is one of the things that influences the ability to absorb the material [3]. Ref. [14] recommended that in addition to prevention activities, promotion of healthy relationship needs to be made, especially among boys and abuser potential groups. In addition to elementary school teachers, similar activities could also be conducted among pre-school teachers.

\section{Acknowledgment}

This work was fully supported by the Directorate Research and Community Service of Department of Research, Technology and Higher Education, Republic of Indonesia, Fiscal year of 2018 .

\section{References}

[1] Noviana, I. (2015). Kekerasan seksual terhadap anak: dampak dan penanganannya (The children sexual abuse: the Impact and its treatment). SosioInforma 01, No. 1.

[2] Brazelton, J. F. (2015). The secret storm: exploring the disclosure process of African American women survivors of child sexual abuse across the life course. Traumatolo-gy: An International Journal, 21(3): 181-187. Viewed May 2nd, 2016. https://doi.org/10.1037/ $\underline{\operatorname{trm} 0000047}$

[3] Wurtele, S.K., (2008). Behavioural approaches to educating young children and their parents about child sexual abuse prevention. The Journal of Behaviour Analysis of Offender and Victim Treatment and Prevention, 1 (1), 52-64. https://doi.org/10.1037/h0100434

[4] Dale, Edgar.(1969).Audio-Visual Methods in Teaching, 3rd ed., Holt, Rinehart \& Winston. New York.

[5] Davis, B. \& Summers, M. (2015). Applying dale's cone of experience to increase learning and retention: A study of student learning in a foundational leadership course. QScience Proceedings: Vol. 2015, Engineering Leaders Conference 2014. West Lafayette. USA. Viewed May 12, 2016. http://www.qscience.com/doi/10.5339/qproc.2015.elc2014.6.

[6] Arsyad, A. (2006). Media Pembelajaran (Educational Media). Raja Grafindo Persada. Jakarta.

[7] Gilakjani, A.P. (2012). The significant role of multimedia in motivating EFL learners interest in English language learning. I.J Modern Education and Computer Science. 4 (8): 57-66. Viewed April 22, 2016. http://www.mecs-press.org/ijmecs/ijmecs-v4-n4/IJMECSV4-N4-8.pdf. 
[8] Bétrancourt, M. (2005).The animation and interactivity principles, in R. E. Mayer (ed.) Handbook of Multimedia. Cambridge University Press. Cambridge. https://doi.org/10.1017/CBO9780511816819.019

[9] Kwasu, A.I., Ema. (2015). Effectiveness of Animated Instructional Resource of Learn-ing Facilitation among Secondary School in Bauchi Nigeria. Journal of Education and Practice, 21 (6):113-120. Viewed April 26, 2016. http://files.eric.ed.gov/fulltext/ EJ1079103.pdf.

[10] Scholes,L., Jones, C.,Stieler-Hunt, C., Rolfe, B. \& Pozzebon, K. (2012).The teachers' role in child sexual abuse prevention programs: implications for teacher education. Australian Journal of Teacher Education, 37(11), 104-131. https://doi.org/10.14221/ajte.2012 $\underline{\mathrm{v} 37 \mathrm{n} 11.5}$

[11] Hebert, M., Lavole, F., Parent, N. (2002). An assessment of outcomes following par-ents' participation in child abuse prevention program. Violence and Victim, 17 (3). https://doi.org/10.1891/vivi.17.3.355.33664

[12] Fryda, C. M. \& Hulme, P.A., (2015).School-based childhood sexual abuse prevention programs: an integrative review. The Journal of School Nursing, 31(3) 167-182..

[13] Zhang, W., Chen, J., Feng, Y., Li, J., Liu, C., Zhao, X. (2014). Evaluation of a sexual abuse prevention education for Chinese pre-schoolers. Research on Social Work Prac-tice, (24): 428-436. https://doi.org/10.1177/1049731513510409

[14] Bolen, R.M.(2003). Child sexual abuse: prevention or promotion? Social Work, 48 (2), 174-185. https://doi.org/10.1093/sw/48.2.174

[15] Saputra, A. Z. (2016). Perancangan animasi infografis pendidikan seksual usia dini un-tuk orang tua anak usia 5-10 tahun (The Design of Animation Info-graphic of child-hood sexual education for parents with 5-10 years old children ). Thesis. Fakultas Teknologi Informasi Universitas Kristen Satya Wacana. Salatiga.

\section{Authors}

Eko Sediyono is a member of the IEEE Computer Society, Indonesia Chapter, with member number 41605422. He received his first degree in Statistics from Bogor Agricultural Institute, Bogor, Indonesia, in 1985. He achieved a Master's Degree in Computer Science from Indonesian University in 1994 and his Ph.D. from Computer Science Department of University of Indonesian in 2006. His research interest is in the statistics, data analytic, education technology, and information processing. He is now a professor at the Faculty of Information Technology - Satya Wacana Christian University Salatiga, Indonesia.

Wahyuni Kristinawati is a lecturer at the Faculty of Psychology, Satya Wacana Christian University, Salatiga, Indonesia. She accomplished her Bachelor in Psychology from the Faculty of Psychology of Gajahmada University, Yogyakarta, Indonesia, and finished her Master in Psychology at the Faculty of Psychology of University of Indonesia. Her research interest is in the area of emotion, qualitative research in psychology of violence, especially study of perpetrators. She is actively involved in anti-violence movement in various groups in the community.

Mila Chrismawati Paseleng is a lecturer in the Informatics and Computer Education Program at the Faculty of Information Technology of Satya Wacana Christian University, Salatiga. She achieved her Bachelor in Physics with honor from the Facul- 
ty of Science and Mathematics of Satya Wacana Christian University, Salatiga, Indonesia in 2006 and finished her master in Educational Technology 3 years later at the Faculty of Education of Pelita Harapan University (UPH), Tangerang, Indonesia. She is a member of Indonesia Bachelor of Education Association. Her research interest is in developing and evaluating the usage of Information and Computer Technology (ICT) to support and improve learning, analysis and design strategy to solve the problem in learning process especially for Informatics and Computer at vocational schools or computer subject for public schools. She was also pursuing study to evolve the implementation of technology utilization in teaching and learning process such as multimedia and e-learning. In addition, some of research that she have done related to developing teachers' professional skills on the use technology.

Article submitted 04 October 2018. Final acceptance 17 November 2018. Final version published as submitted by the authors. 